\title{
Lecturer Development Competency Management in Improving the Quality of Education and Teaching
}

\author{
Ali Imron \\ Department of Educational Administration \\ Universitas Negeri Malang, Indonesia \\ ali.imron.fip@um.ac.id \\ Vina Ariesta Dewi \\ Department of Educational Management \\ Universitas Negeri Malang, Indonesia \\ vheena1@yahoo.co.id
}

\author{
Ahmad Sonhadji \\ Department of Educational Administration \\ Universitas Negeri Malang, Indonesia \\ ahmadsonhadji@telkom.net \\ Ahmad Suriansyah \\ Department of Educational Management \\ Lambung Mangkurat University, Indonesia \\ a.suriansyah@yahoo.co.id
}

\author{
Aslamiah \\ Department of Educational Management \\ Lambung Mangkurat University, Indonesia \\ aslamiah.fkip.unlam@gmail.com
}

\begin{abstract}
The development of increasingly rapid science and technology and increasingly complex conditions of human life and the flow of globalization are challenges to the world of education, especially education in universities High. Talking about education at college, then one topic that is immediately float to the surface is low quality of education. In finding the source of problems, lecturers often become first target. In the university environment, lecturers are one of the main needs. The lecturer occupies an important meaning in operational activities of a College high. Lecturers have functions and assignments the principal as an image builder (builder image) and as a bridge between colleges high with the public (students, employees, parents, professionals and etc.), besides having assignments and the main function is that lecturers are also required to be more proactive and responsive respond and straighten various actual problems and issues that are in the middle developing in the community. Based on the idea that lecturers are professional educators and scientists with the main task of transforming, developing and disseminating science, technology and art through education, research and community service. Therefore, lecturers are required to have pedagogical, personality, social, and professional competence. This Qualitative Research was conducted at the Darul Azhar Tanah Bumbu School of Health (STIKES), with the research design and approach used in this study is qualitative research, case studies, multi sites in order to achieve the objectives of the research set to find out how the competency development management description lecturers in improving the quality of education and teaching at research sites (STIKES Darul Azhar Tanah Bumbu). Research on lecturers 'competency development management aimed at improving lecturers' professional competencies is done by conducting in-depth exploration to find models that are considered appropriate for improving professional competence of lecturers because this is directly related to student services and has a significant effect in efforts to improve the quality of education and teaching in education high.
\end{abstract}

Keywords: development management, competency of lecturers, quality of education and teaching

\section{INTRODUCTION}

Based on the idea that lecturers are professional educators and scientists with the main task of transforming, developing and disseminating science, technology and art through education, research and community service. Therefore, lecturers are required to have pedagogical, personality, social, and professional competence. But in reality, the professional competence of private lecturers relating to pedagogical competence and professional competence has not yet provided a special program in the form of training or workshop, work shop that is intensively sustainable related to the implementation of education and learning has not been implemented optimally. Against this background, the author feels the need to examine further the management of lecturer competency development in its relevance which aims to find a model of how management development strategies for improving the professional competence of lecturers in private universities.

Ideally the ability and expertise must be sharpened and developed by universities from time to time, so that the lecturer as a pillar of higher education always have a competitive advantage and quality for the achievement of university goals high. Increased quality of lecturers at higher education can be done with various methods and methods, including by providing education programs and continuous training, improve methods and strategies lecturer development through fulfillment competencies according to their fields based on knowledge, skills and positive work culture, or with sending employees to various universities high leading both inside and abroad to proceed to higher level of formal education or to gain expertise specifically needed by universities, for that every institution or college high is expected to be able to choose the right method or method so as not to there is a waste of time and cost.

Competence is rational behavior in order to achieve the required goals in accordance with the expected conditions. Thus, a competency is addressed by the appearance or performance that can be accounted for (rational) in an effort to achieve goals (Mangkunegara, 2015; Anwar, 2017). Research on lecturer competency 
development management aimed at improving lecturers' professional competence is done by conducting in-depth exploration to find models that are considered appropriate for improving lecturers' professional competencies because this is directly related to student services and the hypothesis is: (1) if lecturers' professional competencies are high, it will have an impact on the quality of student learning services; and (2) if the quality of student learning services is high, it will have a major impact on the quality of graduates, and if the quality of graduates is good then it will have a good impact on the absorption in the world of work and industry.

The planning strategy for developing lecturer competencies is actually an integral part of the higher education development program in general. The success of the program will affect the quality of the college itself. These programs need to be implemented regularly and continuously so that high-quality lecturers are truly created and able to encourage the progress of higher education. On this basis, the development of lecturer professionalism is a very important effort in order to improve the quality of higher education.

The lecturer quality development program in Indonesia has been known since the 70s. Some universities have organized lecturer competency development activities, such as special upgrading for all new lecturers. However, even though it has been going on for a long time, the lecturer competency development program in Indonesia has not shown good results. Some state universities in Indonesia have indeed been included in the list of the best universities in the world, even though they are still in rank. Likewise, with the private sector, there are a number of private universities (PTS) whose quality is reliable and on par with universities abroad. The achievements of the universities in Indonesia could be influenced by the existence of qualified lecturers in the related universities.

Research provides new ideas that have been neglected by observers, implementers, or stakeholder's education. The events contained in the research data source explain that: (1) the neglect of the development of lecturers' potential by universities; (2) the low quality of learning and the education process; (3) decreasing the potential for higher education development; (4) overall decline in institutional performance; and (5) low interest in student learning. If these events are analyzed in more depth, then they occur from things that are general in nature to things that are more specific, namely the decline in professional competence of lecturers which is certainly caused by several factors as supporters.

\section{METHOD}

In this study a qualitative approach is used with a case study research method, considering that this research is an in-depth study of certain social units whose results provide a broad and in-depth description of certain social units or current phenomena. The aim to be achieved in this study is to find out the management model of professional development of lecturers that has been applied at Darul Azhar Tanah Bumbu STIKES and to find the ideal management model to be applied in Darik Azhar Tanah Bumbu STIKES. Therefore, case study research is very appropriate to be used in this study. It is based on the nature of case study research seeks to obtain an explanation of a phenomenon as a whole (holistic) through data originating from various sources of investigation (documents, archives, interviews, observations, artifacts, multiple sources) systematically against individuals, groups, organization or event.

The presence of researchers in the field in qualitative research is very important, because researchers act as the main instrument (key instrument) as well as collecting research data. The role of researchers in this activity is as participant observers. In relation to the research that will be carried out this is moderate participation, because researchers will actively attend and observe all managerial activities in carrying out activities throughout the field research process and try to cooperate with subjects and informants. In addition, researchers play an active role as participants, so that all behaviors that will be observed will appear naturally and without fabrication. Thus, the data generated in this study is truly data that has high validity.

Sources of data in this study are the words and actions of the people interviewed in this case the Chairperson of the STIKES, Assistant Chairperson of Academic Affairs, Assistant Chairperson of the General Administration of Finance and Staffing, Chair of the Nursing Study Program, Chair of the Midwifery Study Program, Program Coordinator Professional Nursing, Lecturers and Students, as well as documents as a source of written data.

In an effort to obtain accurate data there are several techniques. Data collection can be used in accordance with the characteristics of qualitative data collection. In this study used data collection techniques, namely interviews, observation, and document study. In qualitative research, this interview method was carried out freely controlled. This means that interviews are conducted freely so that data is obtained that is broader and deeper. The main points interviewed are related to: (1) how is the description of professional competence and pedagogical competence of lecturers as well as existing models (existing and applied models) in the management of the development of pedagogical competencies and professional competencies of lecturers in the STIKES Darul Azhar Tanah Bumbu environment; (2) how is the management model of the development of pedagogical competencies and professional competencies of lecturers that should be applied in the environment of the Darul Azhar Tanah Bumbu STIKES; and (3) what is the description of the results achieved in the development of pedagogical competencies and professional competencies of lecturers in the STIKES Darul Azhar Tanah Bumbu environment?

The main points of observation are related to: (1) the number of lecturers teaching in the High School; (2) The last education of lecturers teaching in the High School; (3) Lecturer pedagogic competency which includes the understanding of the lecturer to students, design, and implementation learning, evaluation of learning outcomes, development of students to actualize their potential; (4) Competency of the personality of the lecturer (including: the personality of the lecturer who is stable, stable, mature, disciplined, wise and authoritative, a role model for students, and noble); (5) The lecturers 
'professional competencies include broad and profound mastery of learning material; and (6) Lecturers' social competencies which include the ability of teachers or lecturers as part of the community to communicate and interact effectively with students, fellow educators, education staff, guardian parents, and the surrounding community.

For this reason, in order to support the smooth observation of the research, observation instruments were used in the form of cameras and tape recorders, checklist sheets and observation notebooks to record and document all observational activities carried out by researchers. The document has long been used in research as a source of data because in many ways it can be used to study, interpret, and even predict. Documents are divided into official documents and personal documents. In this study the documents used are official documents, namely government documents in this case the personnel records document (lecturers and employees) STIKES Darul Azhar Tanah Bumbu.

Data analysis in this study can be done when the researcher is still in the field and returning from the field. Data analysis was carried out based on an interactive analysis model as developed by Miles, Huberman, and Saldana (2014). Data analysis in this model consists of 4 interacting components, namely: (1) data collection, (2) condensation of data, (3) presentation of data, and (4) drawing conclusions and verification. Checking the validity of the data in this study uses four criteria, namely credibility, transferability, dependability and confirmability. The stages carried out in this study consisted of three stages, namely the stages of orientation, stages of exploration and stages of member check.

\section{RESULTS}

STIKES Darul Azhar Tanah Bumbuis one of the favorite colleges for several regencies in South Kalimantan (Tanah Bumbu, Kota Baru, Pelaihari, Tanah Laut, and surrounding areas), even more so with the fact that STIKES Darul Azhar Tanah Bumbu is the only School of Health Sciences in the Tanah Bumbu Regency and Kota Baru District. STIKES Darul Azhar Tanah Bumbu is one of the favorite colleges, this is because even though the College has been established for 8 years, STIKES Darul Azhar Tanah Bumbu is able to prove its existence in producing graduates - graduates who are well absorbed by the field job with a satisfying percentage.

Speaking of lecturer competencies, there are several competency criteria that must be possessed by a lecturer, namely: pedagogic competence, personality competence, professional competence, social competence. However, in line with the formulation of the problems that have been presented in the previous chapter, the researcher limits the research focus in this study towards (pedagogic competence and professional competence).

Pedagogic competence itself which includes the ability of lecturers to manage student learning which includes understanding of students, designing and implementing learning, evaluating learning outcomes, and developing students to actualize their potential. Pedagogic competency concerns the capabilities mentioned above, of course not released from the formal education level that has been taken by the lecturer concerned.
Based on the results of the interview, it was obtained data that the professional competence and pedagogical competence of the lecturers in Darik Azhar Tanah Bumbu STIKES as a whole were good enough, this was based on the fact that the teaching lecturers had met the criteria set by the DIKTI, including from the education level pursued by At least S2 lecturers, where 14 permanent lecturers who teach at STIKES Darul Azhar Tanah Bumbu, are S2 graduates who are linear in their respective fields of education.

Furthermore, the data obtained relates to its relevance to the professional competence of lecturers, it is known that permanent lecturers who teach in Nursing, Midwifery and Professional Studies Programs must take a linear level of education to the Study Program taught, with the details that permanent lecturers teach in Nursing Study Programs and The Ners profession must be a Bachelor of Nursing graduate, and a Nursing Masters, as well as a permanent lecturer in the Midwifery Study Program then must be a Midwifery and Midwifery Masters graduate.

The criteria for permanent lecturers who teach at the Darul Azhar Tanah Bumbu STIKES, as mentioned above, and specifically on the Tri Dharma implementation points, so far at the point of education and teaching do not experience significant problems, but on the points of research and development and service sometimes experiencing problems, and this will be explained by the researcher further on the explanation points of the obstacles faced in the management of the competency development of the lecturers of STIKES Darul Azhar Tanah Bumbu.

One effort to maintain the professional competency quality of lecturers is by requiring that the lecturer concerned must be a linear graduate with the field / study program he teaches. Even for the nursing study program itself, STIKES Darul Azhar Tanah Bumbu also has a special specialization for its lecturers to teach courses according to their specialization, although not all nursing lecturers have specializations according to the courses taught.

Management of lecturer competency development is the most vital thing as an effort to produce a significant increase in lecturer competencies with the aim of improving the quality of education and teaching. Good management and strategy will determine the effectiveness of the development of existing lecturer competencies. From a number of question points that the researchers submitted obtained the interview data that, the assessment points that must be filled by each student related to the assessment of the competence of the teaching lecturer consisted of 3 main points, namely: pedagogic competence, professional competence and personality, and social competence.

Furthermore specifically, in connection with the existence of SPMI (Internal Quality Assurance System) from the results of interviews that researchers conducted it was known that the implementation of SPMI was conducted in a disciplined manner each semester in order to obtain evaluation results for each lecturer related to competence (professional, pedagogic, and social competence) and to the extent this works quite effectively 
both from the executors of SPMI itself and also from the point of view of the teaching lecturer.

The researcher gets an explanation that the implementation of SPMI is done at the end of each semester, carried out simultaneously in all existing study programs, wherein the lecturers who teach each objectively are all students from each study program concerned, the tool used in the form of a questionnaire which is an assessment sheet which contains a score for each competency point, then each assessment result sheet collected from all students of each study program, the score is summed, assessed, and averaged according to the standard set and if the lecturer concerned gets an accumulation of each assessment - each competency is below the standard value set, the results of the assessment will be the basis for decision making and policy from the STIKES Darul Azhar Tanah Bumbu to give a warning letter in the form of (SP 1, SP 2, SP 3) and then termination if $\mathrm{d}$ the relevant open still does not improve the assessment that has been submitted.

The implementation of the SPMI (Internal Quality Assurance System) that has been implemented so far is considered effective and has a significant positive impact on the management of lecturer competency development. This is judged on the basis of the consideration that the implementation of SPMI makes each lecturer strive to maintain his competence properly (pedagogic competence, professional competence and personality, social competence) through this assessment every lecturer becomes motivated to maintain his quality so that the quality of education and teaching he give it will also be more optimal as it should be, this is evident from the results of the overall recapitulation of the assessment sheet for all STIKES Darul Azhar Tanah Bumbu lecturers from each study program (nursing, midwifery, and professional study programs) of $90 \%$ of the lecturers rated above average standards set by the STIKES Darul Azhar Tanah Bumbu.

The competency assessment of lecturers through the implementation of the SPMI (Internal Quality Assurance System) is felt effective and objective in giving assessments to lecturers who teach at STIKES Darul Azhar Tanah Bumbu, this is evidenced by the efforts to improve each aspect of competence for lecturers who receive assessment below standard, and continues to be maintained and even improved for lecturers who get good ratings and are above the expected standards.

Other forms of effort in the management of lecturer competency development are in the form of giving scholarships to study $\mathrm{S} 2$ and $\mathrm{S} 3$ to the lecturers (in this case prioritized for permanent lecturers) where the awarding of scholarships is a form of commitment from the campus management in developing lecturer competencies especially its relevance to pedagogical competencies and professional competence). This is evidenced by the education level data of the lecturers who teach at STIKES Darul Azhar Tanah Bumbu, this is evidenced by the increase in lecturers' education graduates who since their inception in 2008 , most $(80 \%)$ have $\mathrm{S} 1$ degrees, but now almost entirely has graduated from a post-graduate education program with real support in the form of full scholarship assistance to each of his lecturers in completing post-graduate studies, especially in this case intended for permanent lecturers namely as many as 16 permanent lecturers, 1 doctoral graduate (doctoral program), 13 people including has graduated S2 (Masters), while 2 others are in the process of taking postgraduate studies.

One of the most significant real efforts was the impact on the development of lecturer competencies and greatly helped the lecturers in improving their quality and competency, and the lecturers were very appreciative of the scholarship. Scholarships given to permanent lecturers not only stop until the S2 scholarship, but also the campus provides assistance and support for the lecturers to continue their studies to S3 level, although it is a top priority first so that the permanent lecturers as a whole have completed S2, and also of course there are still a number of considerations from the management of the STIKES Darul Azhar Tanah Bumbu in providing S3 scholarships that must be taken in turns and cannot be given simultaneously to all permanent lecturers because the needs of teaching staff cannot be explained, in other words the given S3 scholarship must be alternately, so that the teaching and learning process continues to run effectively and does not experience obstacles.

The campus also provides cost support facilities for lecturers in attending seminars and training relevant to their knowledge, this is so that the lecturers continue to update and update their knowledge in order to provide quality education and teaching quality that is optimal and in accordance with the times to children his student. In fact, not infrequently the STIKES Darul Azhar Tanah Bumbu party, as a solution to the lack of offers / invitations to seminars and training, STIKES Darul Azhar holds independent seminars (with headlines and themes relevant to the world of health both relevant to the world of nursing and midwifery). support from the STIKES Darul Azhar Tanah Bumbu in developing the competence of the lecturers of STIKES Darul Azhar Tanah Bumbu. Each lecturer is required to meet the minimum standard number of SKP as authentic proof of the participation of the lecturer in seminars and training in other words, each lecturer will be assessed for his / her activeness in continuing to update knowledge in accordance with the times so that the quality of education and teaching will increase.

In the implementation of management development of lecturers' competencies in improving the quality of education and teaching at STIKES Darul Azhar Tanah Bumbu, of course, we cannot be separated from the obstacles faced as a very natural form of reality. Given that in a process certainly does not escape from obstacles and obstacles in its achievement. Even so, the obstacles and obstacles faced do not become a reason for STIKES Darul Azhar Tanah Bumbu to continue to develop the quality and competence of Human Resources (HR) in this case lecturers to maximize the quality of education and teaching given to students and college students.

The obstacle that the researchers found was an obstacle in terms of the obligation for permanent lecturers to fulfill the responsibility of holding 12 credits, while the subjects and tri dharma that were fulfilled were still difficult to fulfill the 12 SKS obligations, so as a solution the permanent lecturers did not fulfill their responsibilities It is charged to teach other courses which is certainly a 
field of expertise, so that the lecturers concerned feel less optimal in providing lecture material. The response of the lecturers of the STIKES Darul Azhar Tanah Bumbu lecturer to the development of lecturer competencies can be seen and can be concluded from interviews and observations. in the field that researchers do. From the interviews conducted, it was obtained data that most of the lecturers greatly appreciated the efforts made by STIKES Darul Azhar Tanah Bumbu in supporting the development of the competence of its lecturers. Most of the lecturers considered that the management of lecturer competency development at STIKES Darul Azhar Tanah Bumbu had gone quite well, and had a significant impact on the development of competencies of the lecturers who taught there, and he hoped that efforts to develop lecturer competency management at STIKES Darul Azhar Tanah Bumbu to be able to continue to be improved.

\section{DISCUSSION}

Competence is a combination of mastery, knowledge, skills, values and attitudes reflected in habits think and act in carry out his duties / work (Saad, 2008). In other words, competence is a basic characteristic that can be associated with improving individual or team performance. Lecturers are one component in learning process that plays a role in the effort to establish resources potential human potential in the field of development with the knowledge he has as well can make students become smart person (Anwar, 2017; Ghaffari, 2017; Blasikova, 2014; Baloch, 2016). In other words, lecturers are professional educators who become a component in the learning process in order to make students become intelligent people and become potential human resources.

Lecturer competency is the ability possessed by lecturers including mastery, knowledge, skills, values and attitudes reflected in the habit of thinking and acting in the learning process that is effective and efficient so that students can become intelligent people and become potential human resources (Ghaffari, 2017). In the Government Regulation of the Republic of Indonesia Number 19 of 2005 concerning National Education Standards, the explanation of Article 28 paragraph 3 cited in Mulyasa (2002), there are four dimensions of competency, namely: (1) pedagogic competency is the ability to manage student learning which includes understanding of students, designing and implementing learning, evaluating learning outcomes, and developing students to actualize their potential; (2) personality competency is the ability of the personality of a teacher, lecturer who is steady, stable, mature, disciplined, wise and authoritative, an example for students, and of a noble character; (3) professional competence is the ability to master learning material widely and deeply; and (4) social competence is the ability of the teacher or lecturer as part of the community to communicate and interact effectively with students, fellow educators, education staff, parents or guardians, and the surrounding community.

Whereas according to Law Number 14 of 2005 concerning Teachers and Lecturers, competency consists of four, namely: (1) pedagogic competency is the ability to manage student learning, (2) personality competency is a strong, noble, wise and authoritative personality ability, (3) professional competence is the ability to master subject matter widely and deeply, and (4) Social competence is the ability of teachers to communicate and interact effectively and efficiently with students, fellow teachers, parents / guardians of students, and the community around.

Competencies and sub-competencies for lecturers can be developed to six points, namely: (1) competence in the field of study; (2) pedagogical competencies; (3) professional ethics competencies; (4) social competencies; (5) research competence; and (6) competence on community service (Salleh, 2016; Gagne, 2005; Coulson, 2008). According to Shahzadi (2014) it is explained that, there are three competencies that need to be given the main attention related to the lecturer competition. When the competition is as follows.

Pedagogic competencies, among the most important sub-competencies are: (1) contributing to curriculum development related to the courses taught; (2) developing course syllabi based on developed competencies; (3) plan the implementation of lectures based on the syllabus that has been developed; (4) designing lecture management, class management, laboratory management; (5) carry out pro-change lectures (active, creative, innovative, experimental, effective, fun, and encourage curiosity); (6) authenticating learning outcomes; (7) guiding students in various aspects; (8) writing textbooks that are synergistic in textual, actual, and factual terms; (9) develop self-professionalism as a lecturer; (10) developing e-learning as one of the learning methods.

Research competencies, among others, are: (1) understanding the philosophy of science in the field of study; (2) mastering classical theories and up-to-date fields of science occupied; (3) understanding the approach to developing the science being pursued; (4) understand research methodology in the field of science; (5) publish research findings; (6) diligently conducting research to solve problems faced by science, society and the state; (7) open to criticism, input and suggestions for improvements to the results of his work.

Community service competencies, among their sub-competencies are: (1) understanding the real problems and offering the right solutions to solve problems faced by the community; (2) establish partnerships synergistically with the community in order to promote and develop each other; (3) establish cooperation with the government; (4) disseminating their knowledge to the public in order to participate in educating the nation; (5) conducting community surveys whose results can be used as consideration in preparing community service programs.

\section{CONCLUSION}

From the description of the discussion and report on the results of the research that has been carried out, it can be concluded: the description of pedagogic competency management and professional competence of lecturers at the STIKES Darul Azhar Tanah Bumbu in improving the quality of education and teaching is good enough. Pedagogic competencies of lecturers at STIKES Darul Azhar Tanah Bumbu are conducting lectures, authenticating learning outcomes, guiding students in various aspects. Professional competency of STIKES 
lecturer Darul Azhar Tanah Bumbu has fulfilled the criteria set by Dikti, the education level pursued is at least S2, where 14 lecturers remain S2 graduates who are linear with education. Lecturer competencies that need to be given the main attention are related to pedagogical competencies, among the most important subcompetencies are: (1) contributing to curriculum development related to the courses taught; (2) developing course syllabi based on developed competencies; (3) plan the implementation of lectures based on the syllabus that has been developed; (4) designing lecture management, class management, laboratory management; (5) carry out pro-change lectures (active, creative, innovative, experimental, effective, fun, and encourage curiosity); (6) authenticating learning outcomes; (7) guiding students in various aspects; (8) writing textbooks that are synergistic in textual, actual, and factual terms; (9) develop selfprofessionalism as a lecturer; (10) developing e-learning as one of the learning methods.

Professional competence of STIKES Darul Azhar Tanah Bumbu lecturers to improve the quality of education and teaching, there are 29 lecturers, as many as 8 graduates from Nursing, and 6 Masters in Midwifery, and 6 non-permanent lecturers with the medical profession. At present almost $87.5 \%$ are S2 graduates, 1 is $\mathrm{S} 3$-educated, the rest have almost finished taking S2 studies. In addition, other indicators are: the presence of specialized nursing study program lecturers (currently STIKES Darul Azhar Tanah Bumbu already has 3 nursing lecturers graduating from S2 with specialization: children and emergency, and this means a significant increase. Lecturers already have S2 education or S3 taught courses according to specialization, training, workshops, symposia, lectures presented expert, comparative study in addition to preparing books and journals for faculty in the library, seminars and workshops.

The program of human resource development can be done through education and training is an effort to improve the ability of intellectual and personal personality of employees The implementation of education and training is one of the efforts to improve the quality of human resources in accordance with the needs of work, to improve human resources in the work unit.) Employee education and training is a job requirement that can be determined in relation $n$ with expertise and knowledge based on activities that are actually carried out at work.

The management of lecturer competency development that has gone so far at STIKES Darul Azhar Tanah Bumbu, has been good and has experienced significant developments. This can be seen from several indicators of increasing education levels of the lecturers through the assistance of full scholarships provided by the campus lecturers, besides that in terms of scientific development it can be seen from the participation of lecturers in seminars and training in the health sector which also helps lecturers to develop their knowledge and expertise in accordance with the times, so that they can provide better quality education and teaching to their students. Besides that, other indicators can also be seen from the results of students' average learning achievement as Bachelor of Nursing, Diploma (D3) Midwifery, and graduating from Nurse STIKES Darul Azhar Tanah Bumbu Professional Education which is 3.10 and $90 \%$ graduates of STIKES Darul Azhar Tanah Spices (Nurse, Nurse and Midwife Professionals) are up to the field of work. The data shows that the quality of education and teaching provided by STIKES Darul Azhar Tanah Bumbu to students - their students are of high quality and successfully educate and print professional Human Resources in the health sector that are needed and ready to work in the community.

\section{REFERENCES}

[1] Anwar, M. 2017. Lecturer Job Performance Study: Motivation, Emotional Intelligence, Organizational Culture and Transformational Leadership as Antecedents with Job Satisfaction as an Intervening. IOSR Journal of Business and Management, 19(6), 1-9.

[2] Baloch, S. 2016. The Influence of Motivation on Performance of Public Sector Employees. GSTF Journal on Business Review, 4 (4), 29-34.

[3] Blasikova, M. 2014. Competences and Competence Model of University Teachers. Procedia Social Behavioral Sciences, 8(159), 457-467

[4] Coulson, J. C. 2008. Exercising at Work and Self Reported Work Performance. International Journal of Workplace Health Management, 1(3), 176-197.

[5] Gagne, M. 2005. Self-Determination Theory and Work Motivation. Journal of Organizational Behavior, 2(6), 331-362.

[6] Ghaffari, S. 2017. The Influence of Motivation on Job Performance: A Case Study at University Technology Malaysia. Australian Journal of Basic and Applied Sciences, 11(4), 92-99.

[7] Mangkunegara, A. P. 2015. Effect of Work Discipline, Work Motivation and Job Satisfaction on Employee Organizational Commitment in the Company. Universal Journal of Management, 3(8), 318-328

[8] Mulyasa, E. 2002. Kurikulum Berbasis Kompetensi. Bandung: Remaja Rosdakarya.

[9] Saad, D. 2018. Impact of Employee Motivation on Work Performance. International Journal of Scientific and Research Publications, 8(3), 295-273.

[10] Salleh, S. M. 2016. The Influence of Work Motivation on Organizational Commitment in the Workplace. Journal of Applied Environmental and Biological Sciences, 6(5), 139-143.

[11] Shahzadi, I. 2014. Impact of Employee Motivation on Employee Performance. European Journal of Business $\begin{array}{lll}\text { and } \quad \text { Management, } & \text { 159-168. }\end{array}$ 